\title{
The Implementation Of Sustainable Development Goals To Stop Marital Rape In Indonesia
}

\author{
Natasya Fila Rais \\ Faculty of Law, Universitas Indonesia, Depok, Indonesia \\ natasya.filarais@gmail.com
}

\begin{abstract}
This study provides a general overview on marital rape, from definition, reasons why such act is conducted, types of cases, and actions that can be taken to stop marital rape. This paper also explains how marital rape cases that happen in Indonesia affects the country's moves in implementing the Sustainable Development Goals, especially goal number 5 about gender equality. Literature study was used as a method to conduct the research for this paper. This paper also explains how policies regarding marital rape in Indonesia are not fully implemented as they were supposedly planned.
\end{abstract}

Keywords-Gender Equality; Human Rights; Marital Rape; Sustainable Development Goals; Women;

\section{INTRODUCTION}

Sustainable Development Goals (SDGs) were created in order to guarantee prosperity and peace for every life on Earth. These goals encourage each country to take action in every aspect of the world, from environment, economy, to education, so they are able to transform the country for the better. One of the goals that are listed in the SDGs is about gender equality, which is stated on number 5. One of the actions that can be taken to serve the purpose of goal number 5 is by eliminating all forms of violence against all women and girls in public and private spheres. One of the forms of violence against women is marital rape. Marital rape, also known as spousal rape or partner rape, is a type of rape that happens between two people who are married or in another type of intimate relationship. 104 countries have outlawed marital rape, however there are still 38 countries that have not, including Indonesia. There are a few reasons why there are countries that have not outlawed such act, such as the demand that says wives should serve their husbands in marriage, opinions that state every sexual intercourse conducted by married couples are considered as consensual, and women have to be obedient towards their spouses and are forbidden to disagree with their husband's decision. According to the prevailing law, Indonesia only recognizes rape as a nonconsensual sexual intercourse towards women outside marriage. It is contrary to the fact that rape can also be done in marriage, towards wives who refuse to have sex with their husbands but are still forced to do so. Indonesia regulates a law on domestic violence, however it does not specifically mention 'marital rape' as one of the forms. By still not protecting wives from marital rape, Indonesia can be considered as a country that has not effectively implemented the gender equality goal in the Sustainable Development Goals. The following paper will explain the reasons why marital rape is conducted, examples of marital rape cases in Indonesia, Indonesia's movements to implement Sustainable Development Goal's gender equality goal, Indonesian government's policies to stop marital rape, and solutions to prevent marital rape.

\section{REASONS Why MARITAL RAPE IS CONDUCTED}

Marital rape is conducted because of various reasons. First, marital rape can occur because of imbalance amount of sexual desire the husband has. In order to fulfil his desire, the husband tends to demand for sexual intercourse towards his wife through verbal, even by using violent force. This can push the husband to force his wife to have non-consensual sexual intercourse with her. Second, wife's refusal to the sexual intercourse the husband is requesting can lead to husband's violent response, which can lead to force nonconsensual sexual act. Third, a husband can force his wife to have sexual intercourse with her because he is under the influence of alcohol. The aforementioned case can lead to violent acts done by the husband, including conducting rape towards his wife. Lastly, other aspects that can be considered as the reasons why marital rape is conducted are economic instability that leads to violent behaviour, the lack of communication between spouses, tendency for the husband to have an affair with another woman, and forced marriage.

Patricia Mahoney explained that marital rape is done because of these reasons:

a) Reinforce power, dominance, and control, as in to express a husband's sexual desire and to define one man's power to control his spouse.

b) Anger expression, as in to express a husband's anger towards his wife for not wanting to have sexual intercourse with him.

c) Stereotype, as in it is a constructed norm that women, as wives are supposed to please their husbands 


\section{EXAMPLES OF MARITAL RAPE CASES IN INDONESIA}

There are a few cases regarding marital rape that occur in Indonesia. For example, marital rape that happened in Bali. A man who worked as a fisherman forced his wife to have sexual intercourse with him. His wife refused to have sexual intercourse with him because she said that she was sick. However, the husband did not accept his wife's excuse and pushed her until she fell. The husband conducted the nonconsensual sexual act while she was still in an extremely weak condition. The wife kept screaming for help, however it was until the husband got out of the house that the neighbours began to come to her house and reported the case to the police. After being held by the police, the husband still stated that he was innocent, however the verdict that was resulted in the courtroom stated that he has violated Article 8 point a and Article 26 of the Elimination of Domestic Violence Act. The husband had to spend 5 month imprisonment in prison for his crime.

Another marital rape case that happened in Indonesia occurred in East Java. A man forced his wife to have sexual intercourse with her in a forest. The husband forced his wife to ride on his motorcycle and go with him, but she refused. The husband told his wife that he would run her with his motorcycle if she did not obey. He was sentenced for his wrongdoing, but he kept stated that it was allowed in the religion. Because she was scared, the wife rode the motorcycle with her husband at high speed. He kept commanding his wife to hold onto him tightly, if the wife refused, he said he would run the motorcycle on purpose. As they arrived at the woods, the husband raped his wife. He was sentenced for 12 years of prison for what he had done.

\section{INDONESIA'S MOVEMENTS TO IMPLEMENT Sustainable DeVelopment Goals' Gender EQuality GOAL}

Goal number 5 of the Sustainable Development Goals (SDGs) encourages UN state members to transform their countries for the better by upholding gender equality. Gender equality has become an important matter in the world, especially in Indonesia. Gender equality is needed to be implemented in every single aspect of social life, such as economy, education, law enforcement, and politics. However, the gender equality reality in Indonesia seems to have not yet met the initial goal. One of the targets in the goal number 5 is to eliminate all forms of harmful practices, including Female Genital Mutilation (FGM). Indonesia has been listed as one of the countries with the highest amount of girls and women who have undergone FGM practice, with the indicated total of 13.4 million of girls who might have experienced such practice.

Despite the fact that there are still several violations of the goal number 5 in Sustainable Development Goals, Indonesia has done efforts in order to promote gender equality. First, the first-ever women's march in Indonesia was held on March 4th, 2017. Several NGOs and communities also gathered to encourage participants to give women similar opportunities in social life, as well as promoting gender equality through other forms, such as the art, by having artists to perform on the event. Second, the government of Indonesia has seen the potential of microbusiness in Indonesia, especially the ones that start in the rural areas. Women, who mostly consisted of housewives, begin to gather and start developing their entrepreneurship skills by creating goods, such as bags from recycled sachets and home decoration from mineral water bottles, in order to make themselves even more productive and also to preserve the environment. Indonesian media also begins to raise awareness gender equality, such as through radio program held in partnership with UN Women and creating campaigns and seminars as well.

\section{A. Indonesian Government's Policies To Stop Marital Rape}

The Indonesian government has done several actions in order to stop sexual violence. However, the actions to stop marital rape specifically have not yet been implemented the way it should be. The Indonesian government has created sets of law in order to prevent sexual violence from happening in the future, to punish the wrongdoers, and to serve justice for the victims. First, the Indonesian Criminal Code regulated a law on rape. On the article 285 of the Criminal Code, it is stated that:

\section{Article 285}

Any person who by using force or threat of force forces a woman to have sexual intercourse with him out of marriage, shall, being guilty of rape, be punished by a maximum imprisonment of twelve years.

A law on rape done towards an unconscious woman is also written on the Article 286 of the Criminal Code, in which it is stated that:

\section{Article 286}

Any person who out of marriage has carnal knowledge of a woman of whom he knows that she is unconscious or helpless, shall be punished by a maximum imprisonment of nine years.

The aforementioned articles stated strict regulations on rape. However, Article 285 and 286 of the Criminal Code only punish the rape conducted by men towards unmarried women. They are not able to be applied to rape conducted in marriage or between a husband and a wife.

The judges in both examples of marital rape cases justified the acts by using the Act number 23/2014 about the Elimination of Domestic Violence. The Article 1 of the Act describes domestic violence as every act, especially towards women, that leads to suffering physically, sexually, and psychologically, as well as household abandonment and the act of and individual taking over another individual's independence (in this case, it is between husband, wife, and their children). Article 8 explains the actions that are considered as sexual violence, such as forced sexual intercourse done towards someone who stays in a particular household and forced sexual intercourse done towards someone in a particular household on the purpose of commercial use and/or other certain purposes. The Article 46 of the Act states the punishment for people who have done sexual domestic violence, which is 12 years amount of maximum prison time or maximum amount of fine of $\mathrm{Rp}$ 
36.000.000. Both articles justify the sexual domestic violence, including stating how justice can be served by punishing the wrongdoers, however the Article 8 does not specify the forms of the sexual violence just like how it is described in the Criminal Code. Each form of sexual violence has its own degree, from the light until the severe form, so one cannot be seen as similar with the other. In terms of determining both prison time and fine, both can be differentiated according to the degree of the crime conducted if the forms are described specifically and categorized.

Indonesia did a ratification based on Convention on the Elimination of All Forms of Discrimination against Women (CEDAW) which was ratified in 1984. However, the implementation of its ratification did not produced big results, even its existence seemed to be unrecognized. In article 16 part IV of this convention, women are guaranteed to have the same rights in marriage. That means, women have similar rights with men to say that they are against non-consensual sexual acts and that they are able to determine whether they have or do not have the desire to conduct sexual act. The aforementioned right tends to be forgotten when the fact that it is one of the most fundamental rights for women.

Indonesia has created a new set of law that ensures the lives of women and to prevent them from experiencing sexual violence. The Act itself condemns sexual control towards another individual (article 7) and individuals that are connected through family line (article 105), including husbands and wives. However, the Act itself has not yet been authorized. Petitions to authorize this Act has been made by several bodies, such as the National Commission of Women, and NGOs.

\section{B. Solutions to Prevent Marital Rape}

There are a few solutions that can be conducted in order to prevent marital rape from happening and to punish the wrongdoers. These actions are needed to be done immediately, so the number of victims can be reduced, even be stopped. By taking actions to end marital rape, the country will also implement the goal number 5 in Sustainable Development Goals. The first action that Indonesia can take is by reevaluating and revising its Criminal Code. By re-evaluating and revising the Criminal Code, the government will be able to come up with the right punishment for spouses who rape their wives and to guarantee the safety of women in the country. Secondly, the Indonesian government needs to specify the categorization of the domestic sexual violence in the Act number 23/2004 based on the degree of its forms. By doing so, the suspects will be punished based on how severe the violence is done, so that fairness and balance will be implemented in the application of the law. Thirdly, the ratification of CEDAW needs to be acknowledged by Indonesian citizens, so that they will know that Indonesia does not tolerate violence against women and has guaranteed the lives of women through the implementation of international law that is recognized by other states. Lastly, Indonesia has to authorize the Act against Sexual Violence as soon as possible. If the Act is authorized, Indonesia will be able to ensure women's safety and protect them from any kind of sexual abuse, including marital rape. By condemning the act of marital rape by way of enforcing the law, Indonesia will not only be able to stop marital rape, but also to implement Sustainable Development Goals based on its original purpose.

\section{CONCLUSIONS}

In conclusion, the Indonesian government has put their efforts in implementing goal number 5 of the Sustainable Development Goals. There are a lot of actions taken by the government, with the help of Non-governmental organizations. However, in terms of marital rape, the law supremacy is still not applied effectively. Other actions, such as campaigns and seminars, are still not able to reach out the entirety of Indonesian citizens. In order to prevent marital rape from happening in the future, there are a lot of ways that the government can take, from re-evaluating acts about sexual violence to creating a new set of law. And by doing so, the government is not just serving justice for victims and suspects of marital rape, but also taking a few steps forward to the equality between genders in Indonesia.

\section{ACKNOWLEDGMENT}

First, I would like to thank God for giving me the opportunity to finish this paper and helping me throughout the writing process. Secondly, I would like to thank my parents, Syofilawati and Rais Daud, for supporting me throughout the process.

\section{REFERENCES}

[1] Campbell, J., \& Alford, P. (1989). The Dark Consequences of Marital Rape. The American Journal of Nursing, 89(7)

[2] Detik News (2013). Dibui Karena Perkosa Istri, Hari Berdalih Dibolehkan Agama, Retrieved October 18, 2017, from, https://news.detik.com/berita/2141032/dibui-karena-perkosa-istri-hariberdalih-dibolehkan-agama/

[3] Detik News (2015). Lagi, Suami Dipenjara Karena Memperkosa Istrinya, Retrieved October 18, 2017, from, https://news.detik.com/berita/d-2959821/lagi-suami-dipenjara-karenamemperkosa-istrinya/

[4] Healthy Place (2016). Marital Rape, Spousal Rape. Retrieved September 1, 2017, from, http://healthyplace.com/abuse/rape/marital-rape-spousalrape/

[5] Koalisi Perempuan Indonesia (2017). Seminar Pentingnya Keadilan dan Kesetaraan Gender di Indonesia. Retrieved October 21, 2017, from, http://www.koalisiperempuan.or.id/2017/01/22/seminar-pentingnyakeadilan-dan-kesetaraan-gender-di-indonesia/

[6] Muyassarotussolichah (2006). Marital Rape pada Masyarakat: Kasus Marital Rape yang Terlapor di Rifka Annisa Tahun 2001-2006. Retrieved October 17, 2017, from, http://www.aifisdigilib.org/uploads/1/3/4/6/13465004/08_muyas.pdf

[7] Pemerintah Negara Kesatuan Republik Indonesia (n.d). Penal Code of Indonesia. Retrieved October 21, 2017, from, http://www.hukumonline.com/pusatdata/detail/1t4c7b7fd88a $8 \mathrm{c} 3 /$ node/38

[8] Riggins, Leah (2006). Criminalizing Marital Rape in Indonesia,24 B.c. Third World L.J. 4221. Retrieved September 1, 2017, from, http://lawdigitalcommons.bc.edu/twlj/vol24/iss2/6/

[9] Scaling Up Nutrition (2016). UN Women Raise Awareness of Gender Equality through Radio in Indonesia. Retrieved October 21, 2017, from, 
http://scalingupnutrition.org/news/un-women-raise-awareness-ofgender-equality-through-radio-in-indonesia/

[10] The Jakarta Post (2016). FGM in Indonesia Hits Alarming Level.

Retrieved

October

21 ,

2017

from

http://www.thejakartapost.com/news/2016/02/06/fgm-indonesia-hits-

alarming-level.html
[11] United Nations (n.d.) Official List of Proposed SDG Indicatiors. Retrieved September 1, 2017, from, http://sustainabledevelopment.un.org/content/documents/11803OfficialList-of-Proposed-SDG-Indicators.pdf 